\title{
Nasopharyngeal Carcinoma (NPC) Risk Factors: A Systematic Review and Meta-Analysis of the Association with Lifestyle, Diets, Socioeconomic and Sociodemographic in Asian Region
}

\author{
Simon I Okekpa ${ }^{1,2}$, Rabiatul Basria S M N Mydin' ${ }^{1 *}$, Ernest Mangantig ${ }^{3}$, Nor \\ Syaffaf Amaliana Azmi ${ }^{1,4}$, Siti Nur Syahirah Zahari ${ }^{5}$, Gurjeet Kaur ${ }^{6}$, Yusri Musa ${ }^{1}$
}

\begin{abstract}
Objective: Risk factors of nasopharyngeal carcinoma (NPC) have been linked with diets, life style and viral infections. NPC is more rampant in Asian populations than non-Asian countries. Our study aims to assess the validity of the suggestions provided by multiple case control studies demonstrating that salted fish consumption, smoking and alcohol consumption are associated with the risk of NPC in Asia. Methods: Search for related literature on salted fish, smoking and alcohol consumption were performed via Science Direct, PubMed databases and Google Scholar. Articles included in this study were from 2009 to 2017, with specific focus on salted fish, smoking and alcohol consumption as risk factors of NPC. This study excluded all articles published prior to 2009 and articles involving other cancers. Data were extracted independently by two different researchers and harmonized. Meta-analysis was conducted on the obtained data, by using R package Meta to create funnel and forest plots. Results: The meta-analysis revealed that salted fish, smoking and alcohol consumption were significantly associated to NPC risk with random effect model score showing OR of 1.41 at $95 \%$ confidence interval (CI) of 1.13-1.75 (P<0.01), OR of 1.89 at $95 \%$ CI of $1.49-2.38$, and OR: 1.42 at $95 \%$ CI of $1.23-1.65$ respectively. Our results also revealed significant association of salted meat, salted vegetables, house type, wood dust exposure associated with NPC risk with $p$ values less than 0.05. Conclusion: This study proposes that salted fish intake, smoking and alcohol consumption might be linked to NPC risk in Asians. Further studies are necessary to ascertain the molecular mechanisms and clarify if the associated path that could function as therapeutic target.
\end{abstract}

Keywords: nasopharyngeal carcinoma risk factors- dietary cancer risk in Asian- tobacco smoking

Asian Pac J Cancer Prev, 20 (11), 3505-3514

\section{Introduction}

Nasopharyngeal carcinoma (NPC) is more common in Asian than in non-Asian countries. In 2012, 86,691 cases $(60,896$ in males and 25,795 in females) of NPC and 50,831 NPC-related deaths (35,753 in males and 15,075 in females) were recorded globally. A total of 68,272 of the NPC cases were from Asia, in which majority of the cases were found in men $(48,492$ in men and 19,780 in women). The highest number of new NPC cases was from China $(33,198)$, followed by Indonesia $(13,084)$, Vietnam $(4,931)$, India $(3,947)$, and Malaysia (2,030) (Mahdavifar et al., 2016). NPC is highly prevalent among the Cantonese population, with an incidence of $>20 / 100,000$ in endemic areas (Zhang et al., 2015).
In Southeast Asia, NPC incidence is high in Malaysia, Indonesia, Singapore, the Philippines, and Vietnam while low in Myanmar, Thailand, Lao republic, and Cambodia (Mahdavifar et al., 2016) The top five Asian countries with the highest age-standardized incidence rate of NPC were Malaysia (7.2 per 100,000), Singapore (6.4 per 100,000), Indonesia (5.6 per 100,000), Vietnam (5.5 per 100,000), and Brunei (4.6 per 100,000) (Mahdavifar et al., 2016). Meanwhile, the top five Asian countries with the highest age-standardized mortality rate were Indonesia (3.4 per 100,000), Vietnam (3.4 per 100,000), Singapore (2.8 per $100,000)$, Malaysia (2.5 per 100,000), and Brunei (2.1 per 100,000) (Mahdavifar et al., 2016).

Several studies have linked lifestyle factors such as smoking and alcohol consumption and dietary factors such

\footnotetext{
${ }^{1}$ Oncological and Radiological Sciences Cluster, Advanced Medical and Dental Institute, ${ }^{3}$ Regenerative Medicine Cluster, Advanced Medical and Dental Institute, Universiti Sains Malaysia, 13200 Bertam, Kepala Batas, Pulau Pinang, ${ }^{4}$ Universiti Teknologi MARA Cawangan Kelantan Kampus Kota Bharu, Wisma KUB, Jalan Sultan Ibrahim, 15050 Kota Bharu, Kelantan, ${ }^{5}$ Universiti Pendidikan Sultan Idris, 35900 Tanjong Malim, Perak Darul Ridzuan, ${ }^{6}$ Institute for Research in Molecular Medicine, Universiti Sains Malaysia,Malaysia, 'Department of Medical Laboratory Science, Faculty of Health Sciences, Ebonyi State University, Abakaliki, 840001 Ebonyi state, Nigeria.*For Correspondence: : rabiatulbasria@usm.my
} 
as consumption of preserved foods with NPC risk (Polesel et al., 2013; Lakhanpal et al., 2014; Ekpanyaskul et al., 2015; He et al., 2015; Lourembam et al., 2015; Xie et al., 2015; Ren et al., 2017; Yong et al., 2017). However, results across various studies have not been entirely consistent. The high incidence of NPC found among the Chinese population in China that migrated to other regions of the world suggests that the dietary habit of this population contributes to NPC development (Chattopadhyay et al., 2017). Due to economic growth and development over the last decade, lifestyle and dietary habits have changed. For example, traditional Chinese diets shifted to western diets (Lee et al., 2003; Cao et al., 2011; Carioli et al., 2017). Thus, modification of dietary habits and changes in environmental factors may have contributed to the recent decreasing trends of NPC in Hong Kong, Taiwan, and Singapore (Tsao et al., 2014). To date, a systematic review of available studies on the risk factors of NPC in Asia remains lacking.

This study aims to provide an updated systematic review and meta-analysis on the daily activities such as consumption of salted fish, alcohol consumption, smoking, smoked meat consumption, sociodemographic factors, socioeconomic factors which could pose threat to human life in terms of their association with increased NPC risk in Asian population.

\section{Materials and Methods}

This study was conducted according to the Preferred Reporting Items for Systematic Reviews and MetaAnalyses (PRISMA) statement.

\section{Search Strategy}

To identify relevant studies for the incidences, mortalities and risk factors of NPC, we searched the Google Scholar, Science Direct, and PubMed databases to identify the relevant publications (Figure 1). The keywords that were used to search for relevant articles are nasopharyngeal cancer, lifestyle, dietary, wood exposure, tobacco smoking, alcohol consumption, salted fish, preserved food, and the incidence of NPC. Also, we performed a manual search for references cited in the selected relevant articles and published reviews to search for additional relevant studies.

\section{Selection Criteria}

The selected studies were screened for eligibility and relevance. The criteria for inclusion in this systematic review are; all publications must have been published within the past 15 years (2003 till 2018), it must be papers that published only nasopharyngeal carcinoma cases, the paper must address the association of lifestyle, dietary, socioeconomic, and sociodemographic factors with NPC risk, and the studies must have case-control design. The exclusion criteria are all publications published before 2003, studies including another type of head and neck cancer (HNC) besides nasopharyngeal cancer and other cancer types, and studies not addressing the association of lifestyle, dietary, socioeconomic, and sociodemographic with NPC risk.

\section{Data Extraction}

The selected studies were reviewed critically. Data were extracted by two independent reviewers and crosschecked to reach consensus. All quantitative results for the association of lifestyle, dietary, socioeconomic, and sociodemographic factors with NPC risk were extracted, and the summary of the evidence for risk factors of NPC are shown in Table 1-6. The following variables from each study were recorded: the first author's last name, publication year, number of cases and controls in the study, the country where the study was performed, data collection method, primary outcome measured in the study, other outcomes measured, odds ratio (OR) estimates with corresponding $95 \%$ confidence interval.

\section{Statistical Analysis}

Meta-analysis was performed for smoking habit and alcohol consumption using the 15 case-control studies reporting association for smoking and 10 case-control studies reporting association for alcohol, respectively. The number of cases and controls from each selected study were used to compute odds ratio and were summarized using random-effect model for two risk factors (smoking habits and alcohol consumption) that were commonly reported in case-control studies. Statistical heterogeneity among the studies included in the meta-analysis was evaluated using $\mathrm{Q}$ and $\mathrm{I}^{2}$ statistics for the two risk factors. Forest plot was computed for smoking habit and alcohol consumption, respectively using $\mathrm{R}$ package meta. Estimation of potential publication bias was executed using funnel plot, in which the standard error of OR of each study was plotted against its OR. An asymmetrical plot suggests possible publication bias. All statistical analyses were performed using $\mathrm{R}$ Software version 3.4.3. A P-value $<0.05$ was considered statistically significant.

\section{Results}

\section{Literature Search}

Figure 1 shows a flowchart of the search process for the studies included in this systematic review and metaanalysis. The characteristics of the selected studies are summarized in Tables 2, 3, 4 and 5. All of the articles included in this study were published between 2003 and 2017. Only studies with the case-control design were included in this review due to the lack of cohort studies on the risk factor of NPC.

During the literature search we were able to identify one hundred and ten (110) articles related to NPC risk that were published between 2003 and 2017. Thirtytwo articles out of the 110 met the stipulated criteria for inclusion in our study while additional three relevant articles were discovered from the reference list of the chosen articles making it a total of thirty-five articles reviewed for this study.

\section{Evidence for risk factors of NPC}

The primary studies on risk factors for NPC are listed in Table 1. Various methods were used to obtain information related to tobacco smoking habits, alcohol drinking, occupational exposure, consumption of salted 
Table 1. Summary of the Case-Control Studies on the Risk Factors Contributed to Nasopharyngeal Cancer

\begin{tabular}{|c|c|c|c|c|}
\hline Sources & Participant, Study location & $\begin{array}{l}\text { Data collection } \\
\text { method }\end{array}$ & Outcome measured & Adjusted OR estimates $(95 \% \mathrm{CI})$ \\
\hline Yong et al., (2017) & $\begin{array}{l}290 \text { cases and controls, } \\
\text { Singapore }\end{array}$ & $\begin{array}{l}\text { Questionnaire } \\
\text { Interview }\end{array}$ & $\begin{array}{l}\text { Salted fish } \\
\text { consumption }\end{array}$ & $\begin{array}{l}\text { Monthly: OR }=1.41(0.88-2.26) \\
\text { Weekly/daily: OR }=4.18(1.69-10.38)\end{array}$ \\
\hline Ren et al., (2017) & $\begin{array}{l}118 \text { patients, } 274 \text { controls, } \\
\text { China }\end{array}$ & $\begin{array}{l}\text { Interviewed via } \\
\text { telephone }\end{array}$ & $\begin{array}{l}\text { salted fish } \\
\text { consumption }\end{array}$ & $\begin{array}{l}\text { Monthly: } \mathrm{OR}=1.53(0.85-2.73) \\
\text { Weekly: OR }=1.71(0.93-3.17)\end{array}$ \\
\hline Ghosh et al., (2014) & $\begin{array}{l}64 \text { cases, } 100 \text { controls, } \\
\text { India }\end{array}$ & $\begin{array}{l}\text { Personal } \\
\text { interview }\end{array}$ & Intake of salted fish & $\mathrm{OR}_{\text {saltedfish }}=2.61$ \\
\hline Yong et al., (2017) & $\begin{array}{l}290 \text { cases and controls, } \\
\text { Singapore }\end{array}$ & $\begin{array}{l}\text { Questionnaire, } \\
\text { Interview }\end{array}$ & Salted meat & $\begin{array}{l}\text { Monthly: OR }=2.04(1.18-3.50) \\
\text { Weekly/daily: OR }=2.18(0.97-4.89)\end{array}$ \\
\hline Yong et al., (2017) & $\begin{array}{l}290 \text { cases and controls, } \\
\text { Singapore }\end{array}$ & $\begin{array}{l}\text { Questionnaire } \\
\text { Interview }\end{array}$ & Salted vegetable & $\begin{array}{l}\text { Monthly: OR }=1.54(0.99-2.39) \\
\text { Weekly/daily: OR }=3.70(1.58-8.64)\end{array}$ \\
\hline Ghosh et al., (2014) & $\begin{array}{l}64 \text { cases, } 100 \text { controls, } \\
\text { India }\end{array}$ & $\begin{array}{l}\text { Personal } \\
\text { interview }\end{array}$ & Intake of smoked fish. & $\mathrm{OR}_{\text {smokedfish }}=2.21$ \\
\hline Yong et al., (2017) & $\begin{array}{l}290 \text { cases and controls, } \\
\text { Singapore }\end{array}$ & $\begin{array}{l}\text { Questionnaire, } \\
\text { Interview }\end{array}$ & Intake of smoked fish & $\begin{array}{l}\text { Monthly: } \mathrm{OR}=0.84(0.47-1.50) \\
\text { Weekly/daily: } \mathrm{OR}=1.33(0.30-5.96)\end{array}$ \\
\hline Ghosh et al., (2014) & $\begin{array}{l}64 \text { cases, } 100 \text { controls, } \\
\text { India }\end{array}$ & $\begin{array}{l}\text { Personal } \\
\text { interview }\end{array}$ & $\begin{array}{l}\text { Intake of smoked } \\
\text { meat, }\end{array}$ & $\mathrm{OR}_{\text {smokemeat }}=2.00$ \\
\hline Yong et al., (2017) & $\begin{array}{l}290 \text { cases and controls, } \\
\text { Singapore }\end{array}$ & $\begin{array}{l}\text { Questionnaire, } \\
\text { Interview }\end{array}$ & $\begin{array}{l}\text { Intake of smoked } \\
\text { meat }\end{array}$ & $\begin{array}{l}\text { Monthly: OR }=0.75(0.47-1.18) \\
\text { Weekly/daily: OR }=1.52(0.55-4.24)\end{array}$ \\
\hline Yong et al., (2017) & $\begin{array}{l}290 \text { cases and controls, } \\
\text { Singapore }\end{array}$ & $\begin{array}{l}\text { Questionnaire, } \\
\text { Interview }\end{array}$ & $\begin{array}{l}\text { Smoking (currently vs } \\
\text { ever-smoke) }\end{array}$ & $\begin{array}{l}\text { Current smokers: } \mathrm{OR}=4.50(2.58-7.86) \\
\text { Former smokers: } \mathrm{OR}=2.52(1.54-4.12)\end{array}$ \\
\hline Ren et al., (2017) & $\begin{array}{l}118 \text { patients, } 274 \text { controls, } \\
\text { China }\end{array}$ & $\begin{array}{l}\text { Interviewed via } \\
\text { telephone }\end{array}$ & Smoking & $\begin{array}{l}\text { 10-30 cigarettes: } \mathrm{OR}=4.03(1.11-14.68) \\
<30 \text { cigarettes: } \mathrm{OR}=11.46(1.26-103.91)\end{array}$ \\
\hline Xie et al., (2015) & $\begin{array}{l}352 \text { cases, } 410 \text { controls, } \\
\text { Hong Kong }\end{array}$ & Questionnaire & $\begin{array}{l}\text { Smoking (currently vs } \\
\text { ex-smoker) }\end{array}$ & $\begin{array}{l}\text { Currently smoking: } \mathrm{OR}_{\text {adj }}=1.67(1.06-2.61) \\
\text { Ex-smoker: } \mathrm{OR}_{\text {adj }}=1.51(0.94-2.41)\end{array}$ \\
\hline He et al., (2015) & $\begin{array}{l}1,845 \text { cases, } 2,275 \text { controls, } \\
\text { Guangdong, China }\end{array}$ & Interview & $\begin{array}{l}\text { Wood combustion, } \\
\text { cigarette smoking, } \\
\text { and family history, } \\
\text { Incense burning }\end{array}$ & $\begin{array}{l}\text { Frequent incense use: } \mathrm{OR}=1.73(1.43-2.09) \\
\text { Wood fuel use: } \mathrm{OR}=1.95(1.65-2.31) \\
\text { Incense burning and cigarette synergistic index } \\
(\mathrm{SI}): \mathrm{OR}=1.67(1.01-2.76) \\
\text { Wood fuel use and family history SI: } \\
\mathrm{OR}=1.77(1.06-2.96)\end{array}$ \\
\hline Lourembam et al., (2015) & $\begin{array}{l}105 \text { cases, } \\
115 \text { controls, North-eastern } \\
\text { India }\end{array}$ & Interview & $\begin{array}{l}\text { Smoked meat } \\
\text { consumption, } \\
\text { exposure to smoke, } \\
\text { living in house with } \\
\text { poor ventilation, and } \\
\text { alcohol consumption }\end{array}$ & $\begin{array}{l}\text { OR }(95 \% \mathrm{CI}) \text { was not determined in the study. } \\
\text { Only p-values were reported: } \\
\text { Smoked meat consumption }=p<0.00001 \\
\text { Exposure to smoke }=p<0.0007 \\
\text { Living in house with poor ventilation }=p<0.0032 \\
\text { Alcohol consumption }=p<0.01\end{array}$ \\
\hline Lakhanpal et al., (2014) & $\begin{array}{l}120 \text { patients, } 100 \text { controls, } \\
\text { India }\end{array}$ & $\begin{array}{l}\text { Questionnaire } \\
\text { Interview }\end{array}$ & $\begin{array}{l}\text { Use of firewood, } \\
\text { living in mud house, } \\
\text { and consumption of } \\
\text { alcohol }\end{array}$ & $\begin{array}{l}\text { Use of fire wood: } \mathrm{OR}=3.79(1.97-7.30) \\
\text { Mud house: } \mathrm{OR}=3.46(1.19-10.08) \\
\text { Alcohol: } \mathrm{OR}=2.11(1.02-4.37)\end{array}$ \\
\hline Ekpanyaskul et al., (2015) & $\begin{array}{l}327 \text { cases, } 327 \text { controls, } \\
\text { Thailand }\end{array}$ & $\begin{array}{l}\text { Personal } \\
\text { interview }\end{array}$ & Wood dust exposure & $\mathrm{OR}=1.62(1.03-2.74)$ \\
\hline Ren et al., (2017). & $\begin{array}{l}118 \text { patients, } 274 \text { controls, } \\
\text { China }\end{array}$ & $\begin{array}{l}\text { Interviewed via } \\
\text { telephone }\end{array}$ & $\begin{array}{l}\text { High school or higher } \\
\text { Education level }\end{array}$ & $\mathrm{OR}=0.58(0.32-1.05)$ \\
\hline
\end{tabular}

OR, Odds Ratio; CI, Confidence Interval.

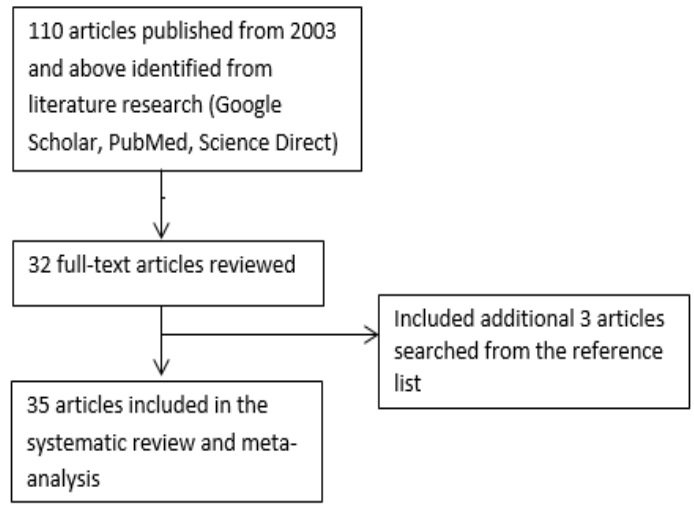

Figure 1. Identification of Relevant Studies for the Incidences, Mortalities and Risk Factors of NPC. Google Scholar, Science Direct, and PubMed databases were searched, and 110 related articles were identified which was screened and trimmed to 35 relevant publications. fish, and other preserved foods. Due to differences in measurement of study factors and adjustment for other confounding factors, the meta-analysis was only conducted for smoking habit, alcohol consumption and consumption of salted fish.

\section{Dietary factors}

Several case-control studies evaluated the association of dietary pattern which refers to intake of salted fish, Salted meat, Salted vegetables, smoked meat, Intake of dark green vegetables, Habitual drinking of herbal tea and preserved vegetables with NPC risk as shown in Table 2. Due to different measurement strategy of the exposure pattern in each study, it was not possible to conduct a meta-analysis to obtain a summary OR for the association of smoked meat, Salted vegetables, Salted meat, Habitual drinking of herbal tea, Intake of dark 
green vegetables and preserved vegetables consumption with NPC risk. Our result revealed that six out of eight studies that reported the association of Salted fish with NPC were significantly associated with NPC risk. Of the three studies that reported the association between smoked meat consumption and NPC risk, two were found to have significant association. For the preserved vegetables consumption and NPC risk, the only one study reported has statistically nonsignificant association. Salted meat and salted vegetables were all significantly associated with NPC risk from the reported data. Two reported data on the intake of dark green vegetables all suggested significant association with NPC.

\section{Meta-analysis for salted fish consumption}

The meta-analysis for salted fish consumption (ever

Table 2. Case-Control Studies on the Association of NPC with Dietary Habits

\begin{tabular}{llc}
\hline Factors & Study & P-value \\
\hline Salted fish & Yong et al, (2017) & 0.033 \\
& Liu et al., (2017) & 0.02 \\
& Xie et al., (2015) & 0.199 \\
& He et al., (2015) & $<0.001$ \\
& Ghosh et al., (2014) & 0.02 \\
& Lakhanpal et al., (2014) & 0.47 \\
& Jia et al., (2010) & 0.001 \\
Salted meat, Salted & Guo et al., (2009) & $<0.001$ \\
vegetables, Preserved & Yong et al, (2017) & $0.003,<0.001 \&$ \\
vegetables \& Smoked & & $0.54,0.06$ \\
meat & Lourembam et al., (2015) & $<0.001$ \\
& Ghosh et al, (2014) & 0.03 \\
Intake of dark green & Xie et al., (2015) & 0.001 \\
vegetables & He et al., (2015) & $<0.001$ \\
Habitual drinking of & Xie et al., (2015) & 0.012 \\
herbal tea & & \\
\hline
\end{tabular}

consumed versus never consumed) are shown in Figure 2. The association between salted fish consumption and risk of NPC was statistically significant in the random effect model $(\mathrm{OR}=1.41 ; 95 \% \mathrm{CI}=1.13-1.75)$ but with a large statistical heterogeneity $\left(\mathrm{I}^{2}=88 \% ; \mathrm{P}<0.01\right)$ between the nine case-control studies included in the meta-analysis. Based on the funnel plot, there is no visual indication of publication bias Figure 3 .

\section{Lifestyle factors}

Fifteen case-control studies that examined the association between smoking habits and NPC risk in Asia were studied (Table 3 ). Of the 15 studies, only ten $(66.7 \%)$ reported that smoking significantly increased the risk for developing NPC. The meta-analysis result obtained from our forest plot in Figure 4 show significant $(\mathrm{OR}=1.89 ; 95 \% \mathrm{CI}=1.49-2.38)$ association of NPC risk with smoking, but with large heterogeneity $\left(\mathrm{I}^{2}=93 \%\right.$; $\mathrm{P}<0.01$ ) as shown in Figure 6a.

The association between alcohol consumption and NPC risk in Asia were assessed from ten case-control studies as shown in Table 4. Only four out of the ten studies reported alcohol significantly increased the risk for NPC. The meta-analysis result obtained from our forest plot in Figure 5 show significant $(\mathrm{OR}=1.42,95 \%$ $\mathrm{CI}=1.23-1.65)$ association of NPC risk with alcohol consumption but with low heterogeneity $\left(\mathrm{I}^{2}=35 \%, \mathrm{P}=0.13\right)$ as shown in Figure 6b.

\section{Meta-analysis for smoking and alcohol consumption}

The results of the meta-analyses for smoking (smoker versus non-smoker) and alcohol consumption (alcohol drinker versus non-drinker) are shown in Figure 4 and 5 , respectively. In meta-analysis, the association between smoking and risk of NPC was statistically significant in the random effect model $(\mathrm{OR}=1.89 ; 95 \%$ $\mathrm{CI}=1.49-2.38$ ) shown in Figure 4. A large statistical

Table 3. Case-Control Studies on NPC Association with Smoking Habit

\begin{tabular}{lccccc}
\hline Study & \multicolumn{2}{c}{ Cases group } & \multicolumn{2}{c}{ Control group } & OR (95\%-CI) \\
& Cases & Total & Control & Total & \\
\hline Xie et al., (2015) & 101 & 352 & 69 & 410 & $1.99(1.41-2.81)$ \\
Lourenbam et al., (2015). & 56 & 105 & 54 & 115 & $1.29(0.76-2.19)$ \\
He et al., (2015). & 972 & 1,845 & 893 & 2,275 & $1.72(1.52-1.95)$ \\
Yong et al., (2017). & 144 & 290 & 78 & 290 & $2.68(1.89-3.79)$ \\
Liu et al., (2017). & 1,390 & 2,499 & 1,368 & 2,576 & $1.11(0.99-1.24)$ \\
Ghosh et al., (2014). & 43 & 64 & 27 & 100 & $5.54(2.79-10.9)$ \\
Tsai et al., (2016). & 73 & 176 & 150 & 352 & $0.95(0.66-1.38)$ \\
Fachiroh et al., (2012). & 404 & 681 & 407 & 1078 & $2.40(1.98-2.93)$ \\
Hashim et al., (2012). & 20 & 96 & 17 & 96 & $1.22(0.60-2.51)$ \\
Ji et al., (2011). & 516 & 1,044 & 312 & 1,095 & $2.45(2.05-2.93)$ \\
Ekburanawat et al., (2010) & 206 & 327 & 147 & 327 & $2.08(1.50-2.85)$ \\
Guo et al., (2009) & 522 & 1,049 & 396 & 785 & $0.97(0.01-1.17)$ \\
Turkoz et al., (2011) & 115 & 183 & 64 & 183 & $3.14(2.05-4.82)$ \\
Cao et al., (2011). & 298 & 462 & 158 & 511 & $4.06(3.11-5.30)$ \\
Yang et al., (2005). & 192 & 502 & 617 & 1,942 & $1.33(1.08-1.63)$ \\
\hline
\end{tabular}

OR, Odds Ratio; CI, Confidence Interval 
Table 4. Case-Control Studies on NPC Association with Alcohol Consumption

\begin{tabular}{lccccc}
\hline Study & Cases group & \multicolumn{2}{c}{ Control group } & OR (95\%-CI) \\
& Cases & Total & Control & Total & \\
\hline Yong et al., (2017) & 176 & 290 & 170 & 290 & $1.09(0.78-1.52)$ \\
Tsai et al., (2016). & 72 & 176 & 124 & 352 & $1.27(0.88-1.85)$ \\
Lakhanpal et al., (2015) & 69 & 120 & 39 & 100 & $2.12(1.23-3.63)$ \\
Lourenbam et al., (2015) & 59 & 105 & 45 & 115 & $2.00(1.17-3.42)$ \\
Ghosh et al., (2014) & 43 & 64 & 49 & 100 & $2.13(1.11-4.09)$ \\
Fachiroh et al., (2012) & 386 & 681 & 475 & 1078 & $1.66(1.37-2.02)$ \\
Hashim et al., (2012) & 10 & 96 & 10 & 96 & $1.00(0.40-2.52)$ \\
Ji et al., (2011) & 243 & 1,044 & 218 & 1,095 & $1.22(0.99-1.50)$ \\
Ekburanawat et al., (2010) & 198 & 327 & 181 & 327 & $1.24(0.91-1.69)$ \\
Turkoz et al., (2011) & 34 & 183 & 23 & 183 & $1.59(0.89-2.82)$ \\
\hline
\end{tabular}

$\begin{array}{ll}\text { Source } & \text { OR }(95 \% \mathrm{Cl}) \\ \text { Yong et al } & 1.78[1.04 ; 3.07] \\ \text { Liu et al } & 1.00[0.88 ; 1.13] \\ \text { Wang et al } & 0.99[0.63 ; 1.57] \\ \text { Xie et al } & 1.04[0.78 ; 1.40] \\ \text { He et al } & 2.03[1.70 ; 2.42] \\ \text { Fachiroh et al } & 1.26[1.04 ; 1.53] \\ \text { Jia et al } & 1.91[1.56 ; 2.34] \\ \text { Ekburanawat et al } & 1.39[0.91 ; 2.14] \\ \text { Guo et al } & 1.66[1.34 ; 2.05] \\ \text { Total (fixed effect) } & 1.36[1.27 ; 1.46] \\ \text { Total (random effects) } & 1.41[1.13 ; 1.75] \\ \text { Heterogeneity: } \chi_{8}^{2}=64.29(P<.01), I^{2}=88 \%\end{array}$

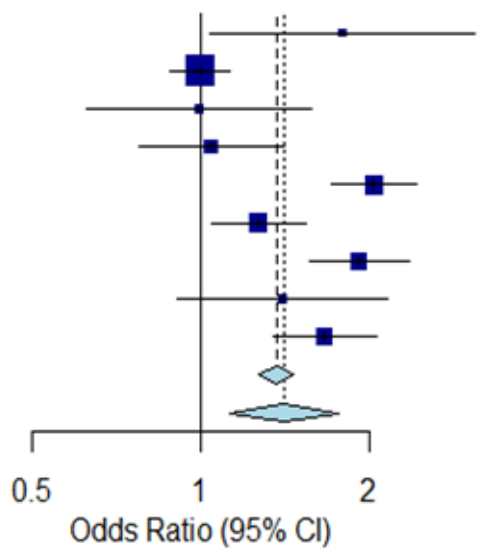

Figure 2. Forest Plot for Salted Fish Consumption and NPC Risk. The Individual horizontal line as seen on the forest plot is representing a single study with the blue box portraying the result plotted while the line shows the $95 \%$ confidence interval of the displayed result. The bigger the box, the larger the size of the study. The diamond shape at the lowermost part of the plot demonstrates the average of the combined result (1.41) of all the individual studies whereas the $95 \%$ confidence intervals $(1.13 ; 1.75)$ is represented by the horizontal points of the diamond. The horizontal points of the diamond did not cross the vertical line, therefore our study detected statistically significant differences between the studies. $\mathrm{I}^{2}$ statistic provided an idea on heterogeneity $(88 \%)$ of the studies, therefore showing inconsistency of the studies. Note that any $\mathrm{I}^{2}$ value of $>50 \%$, means inconsistent studies.

Table 5. Case-Control Studies on the Association of NPC with Socioeconomic Factors

\begin{tabular}{|c|c|c|c|}
\hline Factors & Study & Exposure & P-value \\
\hline \multirow[t]{2}{*}{ Occupational exposure } & Hashim et al, 2012 & $\begin{array}{l}\text { No } \\
\text { Yes }\end{array}$ & $<0.001$ \\
\hline & Guo et al., (2009) & $\begin{array}{l}<10 \text { years } \\
\geq 10 \text { years }\end{array}$ & $\begin{array}{l}0.99 \\
0.001\end{array}$ \\
\hline Dust exposure & Lourembam et al., (2015) & Ever & 0.21 \\
\hline \multirow[t]{4}{*}{ Type of household } & Liu et al., (2017) & $\begin{array}{l}\text { Building/concrete } \\
\text { Cottage/clay brick. }\end{array}$ & $<0.001$ \\
\hline & He et al., (2015) & $\begin{array}{l}\text { Block } \\
\text { Bungalow }\end{array}$ & $<0.001$ \\
\hline & Xie et al., (2015) & $\begin{array}{l}\text { Public rental housing estates } \\
\text { Homeownership scheme courts } \\
\text { Private mansion houses } \\
\text { Private tenement houses }\end{array}$ & $<0.001$ \\
\hline & Lakhanpal et al., (2014) & $\begin{array}{l}\text { Brick/concrete } \\
\text { Mud } \\
\text { Semi-brick/concrete }\end{array}$ & $\begin{array}{l}- \\
0.02 \\
0.99\end{array}$ \\
\hline Poor ventilated house. & Lourembam et al., (2015) & Poor ventilated house & 0.0032 \\
\hline Smoke Exposure & Lourembam et al., (2015) & Smoke Exposure & 0.0007 \\
\hline Cooking experience at home & Xie et al., (2015) & Cooking fumes & 0.005 \\
\hline
\end{tabular}




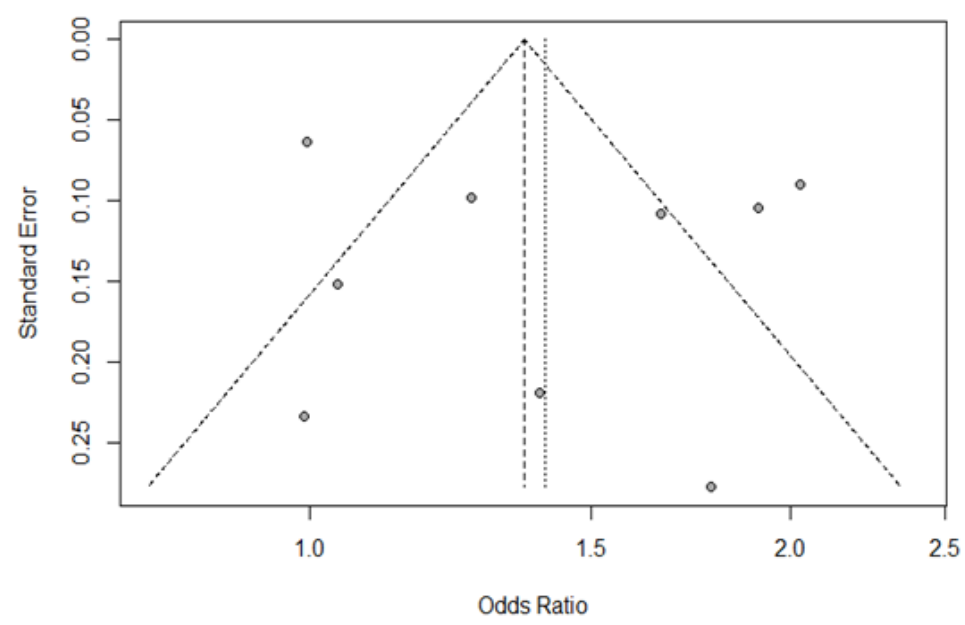

Figure 3. Funnel Plot for Salted Fish Consumption. Each dot signifies individual study. The standard error of the effect estimate is represented by $\mathrm{y}$-axis. X-axis represents the result/odds ratio for the study. Towards the top are larger studies with higher power while toward the bottom are studies with lower power. The scatter in the plot is because of sampling variation. The shape and scatter of the plot is due to variety of standard errors in the studies. Assuming the studies have the same size of standard errors, all the studies/dots would have dropped on the horizontal line.

Table 6. Case-Control Studies on the Association of NPC with Sociodemographic Factors

\begin{tabular}{llll}
\hline Factors & Study & Groups compared & p-value \\
\hline $\begin{array}{l}\text { Level of } \\
\text { education }\end{array}$ & $\begin{array}{l}\text { Xie et al., } \\
(2015)\end{array}$ & None & $<0.001$ \\
& & $\begin{array}{l}\text { Primary } \\
\text { Secondary }\end{array}$ & \\
& He et al., & Primary & 0.63 \\
$(2015)$ & Secondary & \\
& & College & \\
& Fachiroh et & $\leq 12$ years & $<0.001$ \\
al., (2012) & $>12$ years & \\
& Jia et al., & None/Primary & 0.99 \\
& (2010). & Secondary & \\
& & High school. & \\
\hline
\end{tabular}

heterogeneity shown among the 15 case-control studies included in the meta-analysis $\left(\mathrm{I}^{2}=93 \% ; \mathrm{P}<0.01\right)$. As the case-control studies have different study characteristics and study factors, we could not conduct further metaregression analysis to investigate other factors that could potentially influence the summary odds ratio for NPC risk. Based on the funnel plot, there is no visual indication of publication bias (Kendall tau $=0.54, \mathrm{P}=0.59$ ).

For alcohol consumption in Figure 5, meta-analysis reveals a significant association in the random effect model $(\mathrm{OR}=1.42,95 \% \mathrm{CI}=1.23-1.65)$. A low statistical heterogeneity was shown among the ten case-control studies $\left(\mathrm{I}^{2}=35 \%, \mathrm{P}=0.13\right)$. The funnel plot did not show evidence of publication bias (Kendall tau $=0.45, \mathrm{P}=0.65$ ).

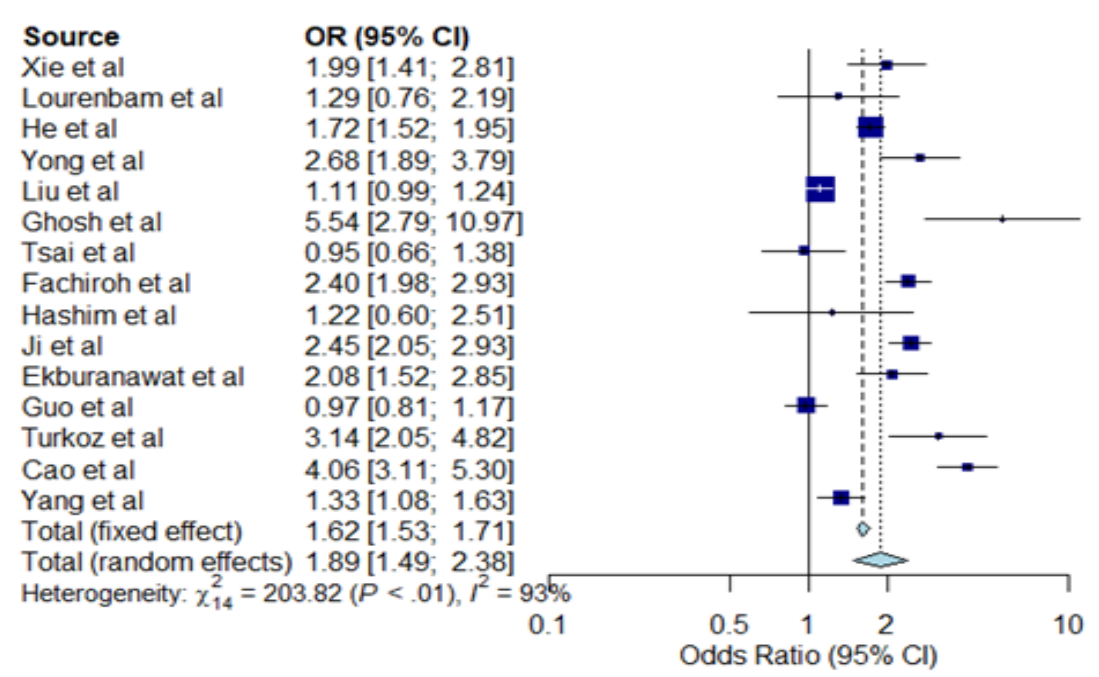

Figure 4. Forest Plot for Smoking Habit and NPC Risk. The Individual horizontal line as seen on the forest plot is representing a single study with the blue box portraying the result plotted while the line shows the $95 \%$ confidence interval of the displayed result. The bigger the box, the larger the size of the study. The diamond shape at the lowermost part of the plot demonstrates the average of the combined result (1.89) of all the individual studies whereas the $95 \%$ confidence intervals $(1.49 ; 2.38)$ is represented by the horizontal points of the diamond. The horizontal points of the diamond did not cross the vertical line; therefore, our study detected a statistically significant difference between the studies. I2 statistic provided an idea on heterogeneity (93\%) of the studies, therefore showing inconsistency of the studies. Note that any I 2 value of $>50 \%$, means inconsistent studies 


$\begin{array}{ll}\text { Source } & \text { OR }(95 \% \mathrm{Cl}) \\ \text { Yong et al } & 1.09[0.78 ; 1.52] \\ \text { Tsai et al } & 1.27[0.88 ; 1.85] \\ \text { Lakhanpal et al } & 2.12[1.23 ; 3.63] \\ \text { Lourenbam et al } & 2.00[1.17 ; 3.42] \\ \text { Ghosh et al } & 2.13[1.11 ; 4.09] \\ \text { Fachiroh et al } & 1.66[1.37 ; 2.02] \\ \text { Nikman et al } & 1.00[0.40 ; 2.52] \\ \text { Ji et al } & 1.22[0.99 ; 1.50] \\ \text { Ekburanawat et al } & 1.24[0.91 ; 1.69] \\ \text { Turkoz et al } & 1.59[0.89 ; 2.82] \\ \text { Total (fixed effect) } & 1.41[1.27 ; 1.57] \\ \text { Total (random effects) } & 1.42[1.23 ; 1.65] \\ \text { Heterogeneity: } \chi_{9}^{2}=13.91(P=.13), I^{2}=35 \%\end{array}$

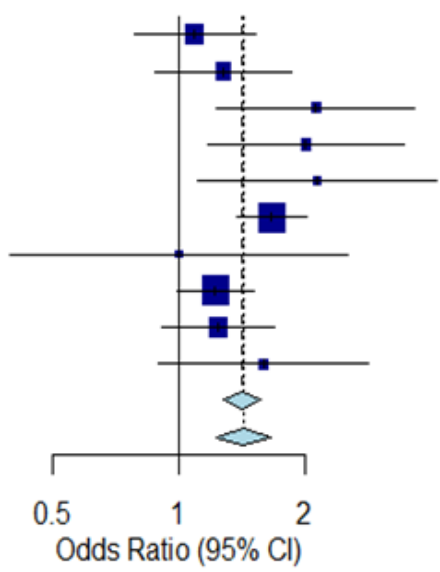

Figure 5. Forest Plot for Alcohol Consumption and NPC Risk. The Individual horizontal line as seen on the forest plot is representing a single study with the blue box portraying the result plotted while the line shows the $95 \%$ confidence interval of the displayed result. The diamond shape at the lowermost part of the plot demonstrates the average of the combined result $(1.42)$ of all the individual studies whereas the $95 \%$ confidence intervals $(1.23 ; 1.65)$ is represented by the horizontal points of the diamond. The horizontal points of the diamond did not cross the vertical line, therefore our study showed statistically significant difference between the studies. I 2 statistic showed heterogeneity of $35 \%$ between the studies.

$\mathbf{a}$

$\begin{array}{ll}\text { Source } & \text { OR }(95 \% \mathbf{C l}) \\ \text { Yong et al } & 1.09[0.78 ; 1.52] \\ \text { Tsai et al } & 1.27[0.88 ; 1.85] \\ \text { Lakhanpal et al } & 2.12[1.23 ; 3.63] \\ \text { Lourenbam et al } & 2.00[1.17 ; 3.42] \\ \text { Ghosh et al } & 2.13[1.11 ; 4.09] \\ \text { Fachiroh et al } & 1.66[1.37 ; 2.02] \\ \text { Nikman et al } & 1.00[0.40 ; 2.52] \\ \text { Ji et al } & 1.22[0.99 ; 1.50] \\ \text { Ekburanawat et al } & 1.24[0.91 ; 1.69] \\ \text { Turkoz et al } & 1.59[0.89 ; 2.82] \\ \text { Total (fixed effect) } & 1.41[1.27 ; 1.57] \\ \text { Total (random effects) } & 1.42[1.23 ; 1.65] \\ \text { Heterogeneity: } \chi_{9}^{2}=13.91(P=.13), I^{2}=35 \%\end{array}$

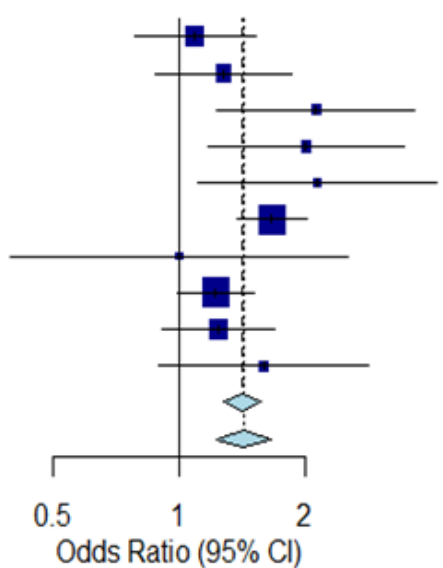

Odds Ratio $(95 \% \mathrm{Cl})$

b

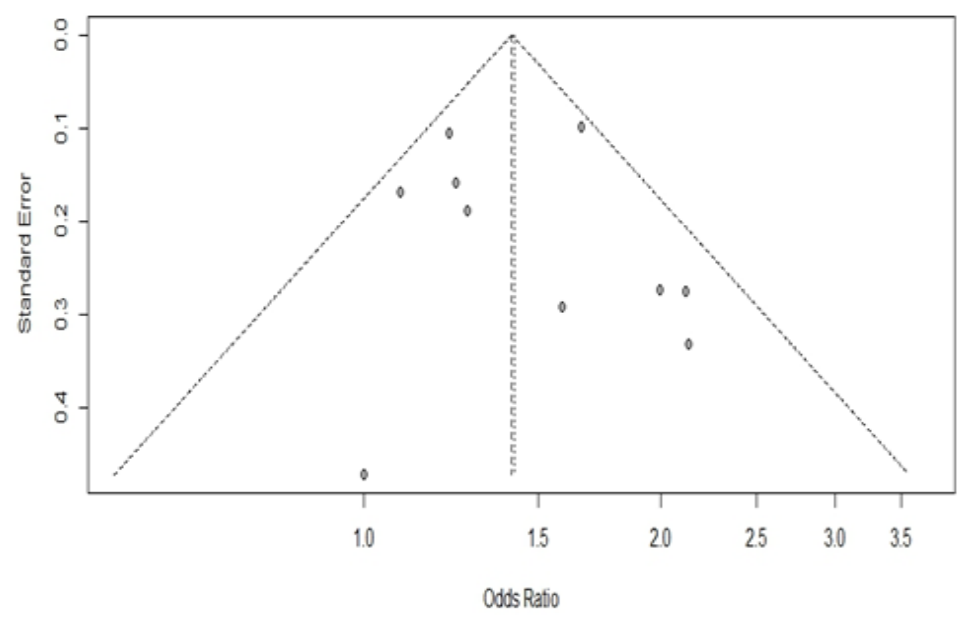

Figure 6. a, Funnel Plot for Smoking Habit. Each dot signifies individual study. The standard error of the effect estimate is represented by $\mathrm{y}$-axis. X-axis represents the result/odds ratio for the study. Towards the top are larger studies with higher power while toward the bottom are studies with lower power. The scatter in the plot is because of sampling variation. The shape and scatter of the plot is due to variety of standard errors in the studies. Assuming the studies have the same size of standard errors, all the studies/dots would have dropped on the horizontal line; $b$, Funnel Plot for Alcohol Consumption. Each dot signifies individual study. The standard error of the effect estimate is represented by $\mathrm{y}$-axis. X-axis represents the result/odds ratio for the study. Towards the top are larger studies with higher power while toward the bottom are studies with lower power. The scatter in the plot is because of sampling variation. The shape and scatter of the plot is due to variety of standard errors in the studies. Assuming the studies have the same size of standard errors, all the studies/dots would have dropped on the horizontal line. 


\section{Socioeconomic factors}

Tables 5 summarized the association of socioeconomic factors such as occupational exposure, wood dust exposure, dust exposure, and type of household with the risk of NPC. For occupational exposure, the only two case-control studies reported, suggested its association with NPC risk, and with both studies showing significant association between occupational exposure and NPC risk. For dust exposure, data obtained from the studies indicate non-significant association with NPC risk. For the type of household, five out of the six published studies found a significant association with NPC risk (Table 4). However, it was not possible to conduct a meta-analysis due to different types of the household definition used in each study.

\section{Socio-demographic factors}

The association of NPC and sociodemographic factors such as education level were studied and summarized in Table 6. For education level, two (50\%) out of the four case-control studies reported a significant association between education level and NPC risk. However, the summary effect was not computed using meta-analysis due to a different measure of education level in each study.

\section{Discussion}

Our meta-analysis summarizing the results from case-control studies suggests a statistically significant association of salted fish consumption with NPC risk. Our results also suggest a significant association of tobacco smoking and alcohol consumption with NPC risk, considering substantial heterogeneity across the studies.

Salted fish consumption has significant association with NPC risk. Our Meta-analysis revealed significant association of salted fish to NPC risk with random effect model score showing OR of 1.41 at $95 \%$ confidence interval (CI) of 1.13-1.75 $(\mathrm{P}<0.01)$. Previous studies have demonstrated that the processes of preserving fish with salt triggers high nitrosamines accumulation which is carcinogenic (Chattopadhyay et al., 2017; Yong et al, 2017). Several foods such as salted fish and various preserved foods containing nitrosamines increase the incidence rate of NPC (Lo et al., 2004). In Southern China, an increase in NPC during childhood was significantly associated with salted fish consumption as reported by Zheng et al., (1994) in their previous work. An anthropological study survey conducted by Zheng et al., (1994), on living practices in high-NPC endemic regions and the association of preserved food consumption with NPC revealed that salted fish consumption significantly raises NPC risk with an odds ratio (OR) of 3.8 (p value $=0.005$ ) from the multivariate analysis (Zheng et al., 1994). Several case-control studies (Table 2) found a statistically significant association between salted fish consumption and NPC risk. These studies suggest that intake of salted fish could induce the development of NPC. Studies in many Asian countries reported that people who consume salted vegetables at least once a week are at higher NPC risk than those who rarely or never consumed such food (Yuan et al., 2000; Jia et al., 2010).
Previous studies have suggested that tobacco smoke contains high levels of nitrosamines, which have been associated with cancers, including NPC (Poirier et al., 1987; Yu et al., 1988). The association of smoking with NPC is related to squamous cells (Xue et al., 2013). Carcinogenic mechanism associated with tobacco smoke is initiated by direct contact of smoke with the epithelium of the nasopharynx, leading to direct action of the chemicals on the nasopharynx. Tobacco may also be contaminated with Epstein-Barr-virus-activating substances, which are significantly associated with undifferentiated nasopharyngeal cancer carcinoma (Jia and Qin, 2012).

The meta-analysis revealed that alcohol consumption was significantly associated to NPC risk with random effect model score showing OR: 1.42 at $95 \%$ CI of $1.23-1.65$. Alcohol is metabolized into acetaldehyde (AA) which adheres to proteins and DNAs to generate DNA carcinogenic adducts (Seitz and Mueller, 2015).

We also observed that consumption of salted vegetables and salted meat have significant association with the increased risk of NPC development (Table 2). This outcome is consistent with the previous studies conducted by Lee et al., (1994) (in Singapore) and Armstrong et al., (1998) (in Malaysia) which suggested that regular eating of salted vegetables can lead to increased risk of NPC (Lee et al., 1994; Armstrong et al., 1998).

Our observation suggests that occupational exposure to wood dust was associated with increased risk of NPC. This result agrees with previous studies which have observed previously an association between wood exposure and nasal tumors (Loprieno, 1975; Vaughan and Davis, 1991). This association between NPC and wood can be attributed to chemicals such as chlorophenols used for wood preservation in wood industry (Hardell et al., 1982; Hardell et al., 1983).

The results for the association of the house type with NPC risk is significant according to our data. Several other reports have shown significant NPC association with different types of house (Hildesheim et al., 2001). Disparity in the measurements of the parameters studied in our sources of data limit the current meta-analysis. Overall, data collected in this study show some evidence that daily activities could increase the risk of developing NPC. However, this review did not discuss the molecular involvement of genes in the pathogenesis of NPC caused by these risk factors.

\section{Acknowledgments}

The authors would like to thank Universiti Sains Malaysia (USM) FRGS research grant (203. CIPPT.6711737) for funding this project and Tertiary education trust fund Nigeria for sponsoring the student.

\section{Conflicts of Interest \\ No conflict of interest exist among the authors.}

\section{References}

Armstrong, RW, Imrey, PB, Lye MS, et al (1998). Nasopharyngeal 
carcinoma in Malaysian Chinese: salted fish and other dietary exposures. Int $J$ Cancer, 77, 228-35.

Cao SM, Simons MJ, Qian CN (2011). The prevalence and prevention of nasopharyngeal carcinoma in China. Chin $J$ Cancer, 30, 114.

Cao Y, Miao X, Huang P, et al (2006). Polymorphisms of XRCC1 genes and risk of nasopharyngeal carcinoma in the Cantonese population. BMC Cancer, $\mathbf{6}, 167$.

Carioli, G, Negri, E, Kawakita, D, et al (2017). Global trends in nasopharyngeal cancer mortality since 1970 and predictions for 2020: Focus on low-risk areas. Int $J$ cancer, 140, 2256-64.

Chattopadhyay NR, Das P, Chatterjee K, Choudhuri T (2017). Higher incidence of nasopharyngeal carcinoma in some regions in the world confers for interplay between genetic factors and external stimuli. Drug Disco Thera, 11, 170-80.

Ekburanawat W, Ekpanyaskul C, Brennan P, et al (2010). Evaluation of non-viral risk factors for nasopharyngeal carcinoma in Thailand: results from a case-control study. Asian Pac J Cancer Prev, 11, 929-32.

Ekpanyaskul C, Sangrajrang S, Ekburanawat W, et al (2015). Semi-quantitative exposure assessment of occupational exposure to wood dust and nasopharyngeal cancer risk. Asian Pac J Cancer Prev, 16, 4339-45.

Fachiroh J, Sangrajrang S, Johansson, M, et al (2012). Tobacco consumption and genetic susceptibility to nasopharyngeal carcinoma (NPC) in Thailand. Cancer Causes Control, 23, 1995-2002.

Ghosh SK, Singh AS, Mondal R, et al (2014). Dysfunction of mitochondria due to environmental carcinogens in nasopharyngeal carcinoma in the ethnic group of Northeast Indian population. Tumor Biol, 35, 6715-24.

Guo X, Johnson RC, Deng H, et al (2009). Evaluation of nonviral risk factors for nasopharyngeal carcinoma in a high-risk population of Southern China. Int J Cancer, 124, 2942-7.

Hardell L, Axelson O, Rappe C (1983). Nasal cancer and chlorophenols. Lancet, 321, 1167

Hardell L, Johansson B, Axelson O (1982). Epidemiological study of nasal and nasopharyngeal cancer and their relation to phenoxy acid or chlorophenol exposure. Am J Ind Med, 3, 247-57.

Hashim NA, Ramzi NH, Velapasamy S, et al (2012). Identification of genetic and non-genetic risk factors for nasopharyngeal carcinoma in a Southeast Asian population. Asian Pac J Cancer Prev, 13, 6005-10.

He YQ, Xue WQ, Shen GP, et al (2015). Household inhalants exposure and nasopharyngeal carcinoma risk: a large-scale case-control study in Guangdong, China. BMC Cancer, 15, 1022 .

Hildesheim A, Dosemeci M, Chan CC, et al (2001). Occupational exposure to wood, formaldehyde, and solvents and risk of nasopharyngeal carcinoma. Cancer Epidemiol Prev Biomarkers, 10, 1145-53.

Ji X, Zhang W, Xie C, et al (2011). Nasopharyngeal carcinoma risk by histologic type in central China: impact of smoking, alcohol and family history. Int J Cancer, 129, 724-32.

Jia WH, Luo XY, Feng BJ, et al (2010). Traditional Cantonese diet and nasopharyngeal carcinoma risk: a large-scale casecontrol study in Guangdong, China. BMC Cancer, 10, 446.

Jia WH, Qin HD. (2012). Non-viral environmental risk factors for nasopharyngeal carcinoma: a systematic review. Semin Cancer Biol, 22, 117-26.

Khlifi R, Olmedo P, Gil F, et al (2014). Risk of laryngeal and nasopharyngeal cancer associated with arsenic and cadmium in the Tunisian population. Environ Sci and Pollut Res, 21, 2032-42.

Lakhanpal M, Singh LC, Rahman T, et al (2015). Contribution of susceptibility locus at HLA class I region and environmental factors to occurrence of nasopharyngeal cancer in Northeast India. Tumor Biol, 36, 3061-73.

Lee AW, Foo W, Mang O, et al (2003). Changing epidemiology of nasopharyngeal carcinoma in Hong Kong over a 20-year period (1980-99): an encouraging reduction in both incidence and mortality. Int $J$ Cancer, 103, 680-5.

Lee HP, Gourley L, Duffy SW, et al (1994). Preserved foods and nasopharyngeal carcinoma: a case-control study among Singapore Chinese. Int J Cancer, 59, 585-90.

Liu Z, Chang ET, Liu Q, et al (2017). Quantification of familial risk of nasopharyngeal carcinoma in a high-incidence area. Cancer, 123, 2716-25.

Lo KW, To KF, Huang DP (2004). Focus on nasopharyngeal carcinoma. Cancer Cell, 5, 423-8.

Lo YL, Pan WH, Hsu WL, et al (2016). Partial least square discriminant analysis discovered a dietary pattern inversely associated with nasopharyngeal carcinoma risk. PLoS One, 11, e0155892.

Loprieno N (1975). International Agency for Research on Cancer (IARC) monographs on the evaluation of carcinogenic risk of chemicals to man:" Relevance of data on mutagenicity". Mutat Res, 31, 210.

Lourembam DS, Singh AR, Sharma TD, et al (2015). Evaluation of risk factors for nasopharyngeal carcinoma in a high-risk area of India, the Northeastern Region. Asian Pac J Cancer Prev, 16, 4927-35.

Mahdavifar N, Ghoncheh M, Mohammadian-Hafshejani A, Khosravi B, Salehiniya H (2016). Epidemiology and inequality in the incidence and mortality of nasopharynx cancer in Asia. Osong Public Health Res Perspect, 7, 360-72.

Poirier S, De-Thé G, Hubert A, et al (1987). Volatile nitrosamine levels in common foods from Tunisia, south China and Greenland, high-risk areas for nasopharyngeal carcinoma (NPC). Int J Cancer, 39, 293-6.

Polesel J, Serraino D, Negri E, et al (2013). Consumption of fruit, vegetables, and other food groups and the risk of nasopharyngeal carcinoma. Cancer Causes Control, 24, 1157-65.

Ren JT, Li MY, Wang XW, et al (2017). Potential factors associated with clinical stage of nasopharyngeal carcinoma at diagnosis: a case-control study. Chin J Cancer, 36, 71.

Seitz HK, Mueller S (2015). Alcohol and cancer: an overview with special emphasis on the role of acetaldehyde and cytochrome P450 2E1. In Biological Basis of Alcohol-Induced Cancer. Springer, Cham, pp 59-70.

Siew SS, Martinsen JI, Kjaerheim K, et al (2017). Occupational exposure to wood dust and risk of nasal and nasopharyngeal cancer: A case-control study among men in four nordic countries-With an emphasis on nasal adenocarcinoma. Int J Cancer, 141, 2430-6.

Tsai CW, Chang WS, Gong CL, et al (2016). Contribution of matrix metallopeptidase-1 genotypes, smoking, alcohol drinking and areca chewing to nasopharyngeal carcinoma susceptibility. Anticancer Res, 36, 3335-40.

Tsao SW, Yip YL, Tsang CM, et al (2014). Etiological factors of nasopharyngeal carcinoma. Oral Oncol, 50, 330-8.

Turkoz FP, Celenkoglu G, Dogu GG, et al (2011). Risk factors of nasopharyngeal carcinoma in Turkey-an epidemiological survey of the Anatolian Society of Medical Oncology. Asian Pac J Cancer Prev, 12, 3017-21.

Vaughan TL, Davis S (1991). Wood dust exposure and squamous cell cancers of the upper respiratory tract. Am J Epidemiol, 133, 560-4.

Xie SH, Yu IT, Tse LA, Au JS, Lau JS (2015). Tobacco smoking, family history, and the risk of nasopharyngeal carcinoma: a case-referent study in Hong Kong Chinese. Cancer Causes 
Control, 26, 913-21.

Xue WQ, Qin HD, Ruan HL, Shugart YY, Jia WH (2013). Quantitative association of tobacco smoking with the risk of nasopharyngeal carcinoma: a comprehensive meta-analysis of studies conducted between 1979 and 2011. Am J Epidemiol, 178, 325-38.

Yang XR, Diehl S, Pfeiffer R, et al (2005). Evaluation of risk factors for nasopharyngeal carcinoma in high-risk nasopharyngeal carcinoma families in Taiwan. Cancer Epidemiol Biomarkers Prev, 14, 900-5.

Yong SK, Ha TC, Yeo MC, et al (2017). Associations of lifestyle and diet with the risk of nasopharyngeal carcinoma in Singapore: a case-control study. Chin J Cancer, 36, 3.

Yu MC, Mo CC, Chong WX, Yeh FS, Henderson BE (1988). Preserved foods and nasopharyngeal carcinoma: a case-control study in Guangxi, China. Cancer Res, 48, 1954-9.

Yuan JM, Wang XL, Xiang YB, et al (2000). Non-dietary risk factors for nasopharyngeal carcinoma in Shanghai, China. Int J Cancer, 85, 364-9.

Zhang LF, Li YH, Xie SH, et al (2015). Incidence trend of nasopharyngeal carcinoma from 1987 to 2011 in Sihui County, Guangdong Province, South China: an age-period-cohort analysis. Chin J Cancer, 34, 15.

Zheng YM, Tuppin P, Hubert A, et al (1994). Environmental and dietary risk factors for nasopharyngeal carcinoma: a case-control study in Zangwu County, Guangxi, China. $\mathrm{Br}$ J Cancer, 69, 508.

Zhou XX, Jia WH, Shen GP, et al (2006). Sequence variants in toll-like receptor 10 are associated with nasopharyngeal carcinoma risk. Cancer Epidemiol Biomarkers Prev, 15, 862-6.

\section{c) (i) (8)}

This work is licensed under a Creative Commons AttributionNon Commercial 4.0 International License. 